\title{
DEVELOPMENT OF TRANSPORT SERVICE MANAGEMENT UNDER THE CONDITIONS OF EUROPEAN INTEGRATION
}

\author{
Liudmyla Boldyrieva*, D.Sc. (Economics), Associate Professor \\ Anastasiia Sydorova, Master Student \\ National University «Yuri Kondratyuk Poltava Polytechnic»
}

* ORCID 0000-0002-9147-5524

(C) Boldyrieva L., 2021.

(C) Sydorova A., 2021.

Стаття отримана редакиією 19.02.2021 p.

The article was received by editorial board on 19.02.2021

Introduction. Transport plays the role of a link in the production logistics chain in terms of both inter-economic and intersectoral integration. Transport as an industry of material production carries out people and goods transportation, in the structure of social production it belongs to the sphere of material services production. The relevance of transport' management and optimization problems are confirmed by the fact that the share of transport costs is $40-50 \%$ of the total logistics costs.

The EU's main goal is to create an environmentally friendly, safe and energy efficient single European transport system. Such circumstances indicate the need for research related to deciding on the strategic directions of transport management development in Ukraine.

Analysis of recent research sources and publications. Researchers from the Slovak Republic Miroslava Nyulasziova and Dana Pal'ova [1], pay attention to the development of digital technologies. They dedicated their publications to the analysis, modeling and optimization of the transport process. Special attention was paid to decision support system designing in this process on the example of a small transport company. For this company scientists have developed an innovative decision support system to improve transport service process management [1].

The team of authors during management decision support system cargo transportation on transport networks study [2] paid attention to the fact that the transport issue is a special case of linear programming general problem. Therefore, according to researchers, it is necessary to use the simplex method as the most well-known method for solving problems of this class [2]. In the course of experimental studies on the optimization of unbalanced cargo traffic, using the developed decision support system, it was concluded that the simplex method is highly effective for finding optimal cargo transport plans for both balanced and unbalanced transport problems [2].

The team of authors carried out research on the application of information technologies for the optimization of itinerary when delivering cargo by automobile transport [3]. R. Gabryelczyk and N. Roztocki analyzed the Business process management success framework for transition economies [4]. Under review by such scientists as A. Goel and S. Irnich was proposed an exact method for vehicle routing and truck driver scheduling problems [5]. Other scientists were studying Using predictive data mining models for data analysis in a logistics company [6] and Logistic and production computer systems in small-medium enterprises [7].

The interesting one is a research related to Variety in freight transport service procurement approaches [8], which showed that cargo transport is characterized by complexity due to interdependence within supply networks. Based on a case study, scientists have concluded that the variety of approaches to transport services purchase strongly influences the conditions of the vehicles use [8]. D. Topolsek, K. Ciziūnienè and T. Cvahte Ojstersek [9] deal with transport logistics issues; logistics and Supply Chain Management is under review of M. Christopher [10]; international transport logistics system was considered by S. C. Lin [11].

Task statement. To investigate the development of transport management in the context of European integration. 
Results. Ukraine's transport system consists of transport infrastructure, vehicles and a management system. The largest volume of cargo turnover is carried out by road and rail transport. Thus, in 2019, their share in the overall structure of cargo traffic was 73.4 and $19.6 \%$, accordingly.

In Ukraine, transport is divided into state (public transport) and non-state, which belongs to individual legal entities and individuals.

State transport is subordinated to the Ministry of Infrastructure of Ukraine, which was established by reorganizing the Ministry of Transport and Communications of Ukraine on December 9, 2010. It includes central executive bodies, in particular:

- State Aviation Administration of Ukraine;

- State Agency of Motor Roads of Ukraine;

- State Service of Ukraine for Transport safety;

- State Service of Maritime and River Transport of Ukraine;

- State Agency for Infrastructure Projects of Ukraine.

The structure of JSC "Ukrzaliznytsia" includes six railway departments: South-West, Odesa, Lviv, Donetsk, Dnipro, South.

Authority bodies develop the strategy and tactics of cargo traffic, make plans for rolling stock according to volume (tons) and turnover (ton-kilometers), set tariffs and rates of additional fees for provided services, determine the amount of fines for violations of rail transportation rules. They include departments of the railways, endowed with the authority to organize the transportation process. The departments have rolling stock - locomotives, cars, containers. They own stations, which manage weighing facilities, hoisting and transport mechanisms, warehouses, depots, repair shops.

Industrial transport (IT) is at the disposal of legal entities. It includes factory locomotives and railway cars, cars, electric and autocars, conveyors, pneumatic and hydraulic transport.

The creation of industrial railway transport enterprises (IRTE) is forward-looking.

Pipeline transport is the most economical type of gas, oil and oil products transportation from production sites to areas of their use and processing. The gas transportation system (GTS) of Ukraine is one of the largest gas transportation systems in the world and performs two main functions: 1) provides domestic consumers with natural gas; 2) transits natural gas to the countries of Western and Central Europe through the territory of Ukraine.

Transportation as a key integrated activity related to the movement of material resources, progressing production or finished products by a particular vehicle in the logistics chain, which in turn consists of complex and basic activities covering forwarding, cargo processing, packaging, giving a right to possess cargo , insurance, etc.

Transport plays a dual role in the logistics system: distribution);

- firstly, it is a component of the main functional branches of logistics (procurement, production,

- secondly, transport is one of the branches of the economy in which entrepreneurial activity also develops: transport offers its products on the market of goods and services, it means transport services, for which it receives income and makes a profit.

Being a branch of material production, transport has its products - this is the process of movement, which is characterized by a number of significant features [12]:

- lack of material form, but at the same time materiality by its nature, because in the process of moving material resources are spent: there is wear of rolling stock and service equipment, the work of transport workers is used, etc.;

- impossibility of storage and accumulation, so the transport can have only some reserve of its capacity to meet the needs of transport services;

- epitome in additional transport costs associated with the movement of material flow, so the transport must be used in such a way that transport costs are the lowest under same circumstances;

- attachment to a certain place, district, region (for example, to the place where the roads are located and relevant transport companies exist).

A significant part of logistics operations on the way of material flow from the primary source of raw materials to final consumption is carried out using different vehicles. The cost of these operations is up to $50 \%$ of the total logistics costs. Analysis of cargo transportation dynamics by all types of vehicles in Ukraine for 2015 - 2019 is given in table 1. 
Dynamics of cargo transportation by all types of vehicles

Table 1 within Ukraine for 2015 - 2019, million tons [13; 14]

\begin{tabular}{|l|c|c|c|c|c|c|c|}
\hline \multirow{2}{*}{ Types } & \multicolumn{5}{|c|}{ Years } & \multicolumn{2}{c|}{ Deviation in percent 2019 till: } \\
\cline { 2 - 8 } & 2015 & 2016 & 2017 & 2018 & 2019 & 2015 & 2018 \\
\hline Road $^{1}$ & 1021 & 1086 & 1122 & 1206 & 1147 & 112,3 & 95,1 \\
\hline Railway $^{2}$ & 350 & 343 & 339 & 322 & 313 & 89,4 & 97,2 \\
\hline Pipeline & 97 & 107 & 115 & 109 & 113 & 116,5 & 103,7 \\
\hline Air & 0,1 & 0,1 & 0,1 & 0,1 & 0,1 & 100,0 & 100,0 \\
\hline Waterway & 6 & 7 & 6 & 6 & 6 & 100,0 & 100,0 \\
\hline including: & & & & & & & \\
$\quad$ - maritime; & 3 & 3 & 2 & 2 & 2 & 66,7 & 100,0 \\
$\quad$ river & 3 & 4 & 4 & 4 & 4 & 133,3 & 100,0 \\
\hline Total within Ukraine & 1474 & 1543 & 1582 & 1643 & 1579 & 107,1 & 96,1 \\
\hline
\end{tabular}

${ }^{1}$ Taking into account transportation performed for own needs. Since 2005 - including commercial cargo traffic performed by individual entrepreneurs.

${ }^{2}$ According to JSC "Ukrainian Railways" (since 2000 - transportation of goods).

${ }^{3}$ According to the State Aviation Administration of Ukraine

Analysis of the table 1 shows that in total in 2019 compared to 2018 less cargo was transported, in particular by road transport by $4.9 \%$ and by rail - by $2.8 \%$. According to the general dynamics of all transport types in Ukraine during the research period, two types of transport dominate: road and rail. Most transportation is performed by rail transport.

The structure of transport services exports and imports of Ukraine for 2015 - 2019 is given in table. 2, the analysis of which showed that in 2019 comparing to 2018 exports increased by $55.7 \%$; and imports by $6.5 \%$.

Table 2

Structure of transport services exports and imports of Ukraine for 2015 - 2019, million dollars USA [15]

\begin{tabular}{|l|c|c|c|c|c|c|c|}
\hline \multirow{2}{*}{ Indicators } & \multicolumn{5}{|c|}{ Years } & \multicolumn{2}{c|}{ Deviation (+,-) 2019 till: } \\
\cline { 2 - 8 } & 2015 & 2016 & 2017 & 2018 & 2019 & 2015 & 2018 \\
\hline $\begin{array}{l}\text { Transport } \\
\text { services export }\end{array}$ & 5263,2 & 5300,6 & 5861,4 & 5851,4 & 9109,9 & 3846,7 & 3258,5 \\
\hline $\begin{array}{l}\text { In percent till the } \\
\text { previous year }\end{array}$ & 86,3 & 100,7 & 110,6 & 99,8 & 155,7 & 69,4 p.p. ${ }^{1}$ & 55,9 p.p. \\
\hline $\begin{array}{l}\text { Transport } \\
\text { services import }\end{array}$ & 1153,4 & 989,3 & 1212,1 & 1464,8 & 1559,2 & 405,8 & 94,4 \\
\hline $\begin{array}{l}\text { In percent till the } \\
\text { previous year }\end{array}$ & 83,8 & 85,8 & 122,5 & 120,8 & 106,4 & 22,6 p.p. & (14,4 p.p.) \\
\hline
\end{tabular}

Note: p.p. - percentage points

Transport activities in the context of European integration should develop in the following areas [12]:

- in-depth study of demand using the transport balances of the regions;

- improving the quality and reliability of customer service;

- improvement of the whole loading and unloading as well as warehousing works complex;

- provision of information and forwarding services;

- raising the level of contractual relations;

- development of services;

- creation of enterprises that would be a part of various associations, joint stock companies, leasing companies, etc.;

- creation of intermediary firms for the supply of rolling stock, support service, marketing, advertising;

- the spread of containers use. 
One of the priority tasks of Ukraine in the conditions of European integration is the dynamic development of the domestic transport system with the help of smart technologies. Transport occupies a leading place in the life of any country. Therefore, the improvement of the transport management system is possible only through the introduction of innovative smart technologies.

The use of these technologies in the transport management system is constantly expanding. Conditions for systematic study of their updated versions have appeared. After performing such an analysis, many organizations will have the opportunity to modernize their own transport.

There is a rather independent transport sphere of logistics, in which multifaceted coordination between the participants of the transport process can be considered outside the direct connection with the linked production and storage areas of material flow. At the same time, transport organically fits into the production and trade processes. Therefore, the transport component is included into many logistics tasks.

Transport logistics should include tasks, the solution of which allows to optimize both transport processes and processes related to them. In general, the set of transport logistics tasks covers logistics processes, which include transportation of goods.

The specifics of the logistical approach to the organization of transport processes will be explained using the example of the transport chain links interaction in the process of goods delivery by several types of transport. The basic one is the schematic diagram of the transportation organization, in which the only function of managing the pass-through material flow is missing. The coherence of the links in the promotion of information and finance is objectively low, as there is no one to coordinate their actions.

Fundamentally different is the organization of transportation. The presence of the end-to-end transportation process single operator creates a fundamental opportunity to design the material flow, to achieve the specified parameters at the output.

The use of logistics in transport, as well as in production or trade, transforms these participants into co-operating partners, complementing each other in the transport process. Logistics is the unity of technology, economics and planning. Accordingly, the tasks of transport logistics should include ensuring the technical and technological integration of transport process participants, coordination of their economic interests, as well as the use of unified planning systems.

The main requirement of the renewal logistics concept is to change the traditional organization of transport production to a new one. This necessitates the identification of reorientation centers in the transport chain of flow processes. These can be centers for products processing carried by transport and orders processing concerning the carriage of goods.

Thus, the transport link applies to all other requirements of the production process updating concept. These are the development of a fundamentally new product manufacturing strategy (transport process), the strategy of further final cargo transportation orientation ensuring, based on the focus on the minimum division of labor and the optimal size of transported consignments for the final products markets.

An integrated approach to the transport logistics system is carried out in order to provide rhythmic, timely and high-quality provision of consumers with goods, customers with services, getting cost reductions as consumers, customers and other unsubs in the markets of goods and services interacting with them.

Transport logistics is characterized by elements that are basic in this area of logistics. The main elements are transport links with suppliers and consumers, goods which are transported. The transportation process begins with finished products warehouses, ends with the receipt of goods at the consumer's warehouses or intermediaries.

Recently, despite all the difficulties, the use of elements of transport logistics is constantly expanding due to, for example, the introduction of a virtual machine local network, information on the movement of goods in transport flows, the introduction of new accounting methods for material assets.

Logistics principles are basic for the development of optimized solutions quality improving during the transition to private management, which reduces the level of workers incompetence, as well as the creation of information flows that combine transport material flows and the processes of their operation.

Conclusions. However, the implementation of logistics into transport processes is increasingly constrained by the policy of market reforms. On the example of transport policy, it means that market thinking and the practice of using logistics by transport companies are still insufficient. Organizational and economic aspects of transportation are also important. Thus, perhaps the most progressive type of rail transportation is by using containers and packages, and as for the road transportation - by using transport terminals. One of the tasks of transport logistics is to avoid irrational transportation (short-distance by rail transport, unjustified long-distance ones, oncoming, empty, as well as repeated transportation, when the cargo is re-transported, unloaded and loaded at the warehouses of intermediary organizations). The costs of 
this transportation for transport organizations are reflected in their total costs of goods transportation, for shippers and recipients - in the cost of transportation according to rates. For the logistics process, they are reflected in the specific total, current and one-time costs from production to consumption. Therefore, in some cases, irrational repeated transportation may be justified from the point of consumer or manufacturer's view, taking into account complex costs, not just the cost of transportation. In the first case, savings are achieved due to the relative (comparing to the past) reduction in the batch size of products supplied, and as a consequence, acceleration of the turnover of its inventories in warehouses occurs. In the second - the possibility to reduce sorting operations and time spent in the warehouse is provided.

The main results of the study that reflect the scientific novelty and reveal the content of the scientific article are those that have been further developed, namely theoretical approaches to substantiate the development of transport in the conditions of European integration, which, unlike existing ones, include a system of such measures: in-depth study demand using the transport balances of the regions; improving the quality and reliability of customer service; improvement of the whole complex of loading and unloading as well as warehousing works; provision of information and forwarding services; raising the level of contractual relations; creation of enterprises that would be a part of various associations, joint stock companies, leasing companies, etc.; creation of intermediary supplying firms for rolling stock, logistics, marketing and advertising; widespread use of containers.

The scientific and practical significance of the research results concerns the determination of the relationship between the elements of the transport management development system in the conditions of European integration, analysis of its current state in Ukraine, creation and application of its development.

A forward-looking area of further research will be the study of economy logistization through smart technologies.

\section{REFERENCES:}

1. Nyulasziova, M. and Pal'ova, D. (2020), "Implementing a decision support system in the transport process management of a small Slovak transport company", Journal of Entrepreneurship, Management and Innovation (JEMI), vol. 16, no. 1, pp. 75-105. https://doi.org/10.7341/20201613

2. Prokudin, G., Chupaylenko, O., Prokudin, O. and Khobotnia, T. (2021), "Management decision support system freight transportation on transport networks". European Journal of Intelligent Transportation Systems, no. 1(3). https://doi.org/10.31435/rsglobal_ejits/30032021/7352

3. Prokudin, G., Chupaylenko, O., Prokudin, O., Dudnik, O., Dudnik, A., Svatko, V. (2018), "Application of Information Technologies for the Optimization of Itinerary when Delivering Cargo by Automobile Transport”. Eastern-European Journal of Enterprise Technologies, no. 2/3 (92). pp. 51-59. http://doi:10.15587/ 1729-4061.2018.128907

4. Gabryelczyk, R. and Roztocki, N. (2018), "Business process management success framework for transition economies”, Information Systems Management, vol. 5(3), pp. 234-253. http://dx.doi.org/10.1080/10580530. 2018.1477299

5. Goel, A. and Irnich, S. (2016), "An exact method for vehicle routing and truck driver scheduling problems”, Transportation Science, vol. 51(2), pp. 1-18. http://dx.doi.org/10.1287/trsc.2016.0678

6. Muchova, M. Paralic, J. and Nemcik, M. (2017), "Using predictive data mining models for data analysis in a logistics company”, Information Systems Architecture and Technology, vol. 26, pp. 61-170. http://dx.doi.org/10.1007/ 978-3-319-67220-5_15

7. Pighin, M. (2016), "Logistic and production computer systems in small-medium enterprises". In 2016 39th International Convention on Information and Communication Technology, Electronics and Microelectronics (MIPRO). IEEE: Opatija, Croatia, pp. 1168-1172. http://dx.doi.org/10.1109/ MIPRO.2016.7522316

8. Hedvall, K. Duboisa, A. and Linda F. (2017), "Variety in freight transport service procurement approaches”, Transportation Research Procedia, vol. 25, pp. 806-823. https://doi.org/10.1016/j.trpro.2017.05.459

9. Topolsek, D. Ciziūnienè, K. and Cvahte Ojstersek, T. (2018), "Defining transport logistics: a literature review and practitioner opinion based approach”, Transport, no. 33(5), pp. 1196-1203. https://doi.org/10.3846/transport.2018. 6965

10. Christopher, M. (2016), Logistics and Supply Chain Management. FT Press. 328 p.

11. Lin, S. C. (2016), "A fuzzy algorithm to evaluate competitive locations for international transport logistics system”, Journal of Marine Science and Technology, no. 24 (2), pp. 125134. https://doi.org/10.6119/JMST01505114 
12. Komelina, O.V. and Boldyrieva, L.M. (2021) Transportna lohistyka [Transport logistics], National University "Yuri Kondratyuk Poltava Polytechnic”, Poltava, Ukraine.

13. Derzhavna sluzhba statystyky Ukrainy (2020) [Transport of Ukraine for 2019: statistical collection], Kyiv.

14. Derzhavna sluzhba statystyky Ukrainy (2019) [Ukraine in numbers - 2018: statistical collection], Kyiv.

15. Derzhavna sluzhba statystyky Ukrainy (2019) [Statistical bulletin "Exports, imports and transit of goods in Ukraine in 2018”], Kyiv.

\section{УДК 658.7:656}

JEL L91, R41

Болдирєва Людмила Миколаївна, доктор економічних наук, доцент. Сидорова Анастасія Костянтинівна, магістрантка. Національний університет «Полтавська політехніка імені Юрія Кондратюка». Розвиток управління транспортним забезпеченням за умов свроінтеграції. Досліджено транспортну систему України, яка складається із транспортної інфраструктури, власне транспортних засобів та системи управління. Проаналізовано динаміку перевезень вантажів усіма видами транспортних засобів і структуру експорту та імпорту транспортних послуг в Україні. Визначено, що транспорт у системі логістики відіграє подвійну роль: по-перше, він $є$ складовою або компонентом основних функціональних галузей логістики (закупівельної, виробничої, розподільної); по-друге, транспорт є однією з галузей економіки, у якій розвивається й підприємницька діяльність: транспорт пропонує на ринку товарів і послуг свою продукцію - транспортні послуги, за котрі отримує доходи й має прибуток. Визначено, що процес переміщення товарів транспортними засобами характеризується низкою істотних особливостей: відсутністю речової форми; неможливістю зберігання та нагромадження; втіленням у додаткових транспортних витратах, пов'язаних з переміщенням матеріального потоку; прив'язаністю до певного місця, району, регіону (наприклад, до місця, де розташовані шляхи сполучення і є відповідні транспортні підприємства). Доведено, що до транспортної логістики слід віднести завдання, розв'язання яких дозволить оптимізувати як транспортні процеси, так і процеси, пов'язані з ними. Виокремлено напрями розвитку транспортних перевезень в умовах євроінтеграції: поглиблене вивчення попиту 3 використанням транспортних балансів регіонів; підвищення якості й надійності обслуговування клієнтів; удосконалення всього комплексу вантажно-розвантажувальних i складських робіт; надання інформаційних, експедиційних послуг; підвищення рівня договірних відносин; розвиток сервісних послуг; створення підприємств, котрі входили б до складу різних асоціацій, акціонерних товариств, орендних фірм та ін.; створення посередницьких фірм 3 постачання рухомого складу, матеріально-технічного забезпечення, маркетингу, реклами; поширення використання контейнерів. Доведено, що одним із пріоритетних завдань України в умовах євроінтеграції $є$ динамічний розвиток вітчизняної транспортної системи за допомогою смарт-технологій.

Ключові слова: логістика, оптимізація, перевезення, розвиток, рухомий склад, транспортні послуги, управління.

\section{UDC 658.7:656}

JEL L91, R41

Boldyrieva Liudmyla, D.Sc. (Economics), Associate Professor. Sydorova Anastasiia, Master Student. National University «Yuri Kondratyuk Poltava Polytechnic». Development of Transport Service Management under the Conditions of European Integration. The transport system of Ukraine, which consists of transport infrastructure, vehicles and management system, is studied in this paper. The dynamics of cargo transportation by all types of vehicles and the structure of exports and imports of transport services in Ukraine are analyzed. It is proved that transport logistics should include tasks, the solution of which will allow optimizing both transport processes and processes related to them. It is distinguished that one of the priority tasks of Ukraine in the conditions of European integration is the dynamic development of the domestic transport system with the help of smart technologies.

Key words: development, logistics, management, optimization, rolling stock, transportation, transport services. 